\title{
Pathogenesis of pediatric B-cell acute lymphoblastic leukemia: Molecular pathways and disease treatments (Review)
}

\author{
FANG-LIANG HUANG ${ }^{1,2}$, EN-CHIH LIAO ${ }^{3}$, CHIA-LING LI $^{1}$, CHUNG-YANG YEN $^{4 *}$ and SHENG-JIE YU ${ }^{5 *}$ \\ ${ }^{1}$ Children's Medical Center, Taichung Veterans General Hospital, Xitun, Taichung 40705; ${ }^{2}$ Department of Physical Therapy, \\ Hungkuang University, Shalu, Taichung 433; ${ }^{3}$ Department of Medicine, Mackay Medical College, Sanzhi, New Taipei 252; \\ ${ }^{4}$ Department of Dermatology, Taichung Veterans General Hospital, Xitun, Taichung 40705; ${ }^{5}$ Department of Medical \\ Education and Research, Kaohsiung Veterans General Hospital, Zuoying, Kaohsiung 813, Taiwan, R.O.C.
}

Received August 17, 2019; Accepted April 3, 2020

DOI: $10.3892 / 01.2020 .11583$

\begin{abstract}
B-cell acute lymphoblastic lymphoma (B-ALL) is a disease found mainly in children and in young adults. B-ALL is characterized by the rapid proliferation of poorly differentiated lymphoid progenitor cells inside the bone marrow. In the United States, 4,000 of these patients are diagnosed each year, accounting for $\sim 30 \%$ of childhood cancer types. The tumorigenesis of the disease involves a number of abnormal gene expressions (including TEL-AML1, BCR-ABL-1, RAS and $P I 3 K$ ) leading to dysregulated cell cycle. Risk factors of B-ALL are the history of parvovirus B 19 infection, high birth weight and exposure to environmental toxins. These risk factors can induce abnormal DNA methylation and DNA damages. Treatment procedures are divided into three phases: Induction, consolidation and maintenance. The goal of treatment is complete remission without relapses. Apart from traditional treatments, newly developed approaches include gene targeting therapy, with the aim of wiping out leukemic cells through the inhibition of mitogen-activated protein kinases and via c-Myb inhibition enhancing sensitivity to chemotherapy. To evaluate the efficacy of ongoing treatments, several indicators are currently used. The indicators include the expression levels of microRNAs (miRs) miR-146a, miR-155, miR-181a and miR-195, and soluble interleukin 2 receptor. Multiple drug resistance and levels of glutathione reductase
\end{abstract}

Correspondence to: Dr Chung-Yang Yen, Department of Dermatology, Taichung Veterans General Hospital, 1650, Sec. 4, Taiwan Blvd, Xitun, Taichung 40705, Taiwan, R.O.C.

E-mail: vernayen@yahoo.com.tw

Dr Sheng-Jie Yu, Department of Medical Education and Research, Kaohsiung Veterans General Hospital, 386 Dazhong 1st Road, Zuoying, Kaohsiung 813, Taiwan, R.O.C.

E-mail: jim0929@msn.com

*Contributed equally

Key words: acute lymphoblastic leukemia, evaluation of treatment efficacy, pathogenesis of leukemia, risk factor, treatment of ALL can affect treatment efficacy through the increased efflux of anti-cancer drugs and weakening the effect of chemotherapy through the reduction of intracellular reactive oxygen species. The present review appraised recent studies on B-ALL regarding its pathogenesis, risk factors, treatments, treatment evaluation and causes of disease relapse. Understanding the mechanisms of B-ALL initiation and causes of treatment failure can help physicians improve disease management and reduce relapses.

\section{Contents}

1. Introduction

2. Pathogenesis

3. Risk factors

4. Treatment

5. Monitoring treatment efficacy

6. Treatment failure

7. Conclusion

\section{Introduction}

Leukemia is characterized by the presence of abnormally large numbers of immature, poorly differentiated white blood cells in the blood; the condition often begins with bone marrow abnormalities (1). In children, acute lymphoblastic leukemia (ALL) is the most common type of blood cancer. In the United States, 4,000 patients are diagnosed each year, accounting for $\sim 30 \%$ of childhood cancer types $(2,3)$. Among these ALL cases, $>80 \%$ result from clonal proliferation of abnormal $\mathrm{B}$ cell progenitors (B-ALL) (4). In recent years, cytosolic signal transduction and molecular abnormality have been shown to play important roles in the pathogenesis of B-ALL; the abnormalities include gene mutations, abnormal protein interaction, unarrested cell cycle and increased autophagy $(5,6)$. Knowledge on these abnormalities could help develop gene targeted therapy. In the wake of medical improvements, increasingly more risk factors have been discovered for B-ALL; minimizing these risk factors could therefore lower its prevalence. Over the last few years, the cure rate of B-ALL has 
substantially been raised. Despite this improvement, relapse rate maintains at $\sim 15 \%$ for patients with B-ALL (7). Such treatment failure could be associated with multiple drug resistance or the abnormal expression of intracellular enzymes.

This present review summarized pediatric B-ALL, its pathogenesis, risk factors, current treatment, and the monitoring of treatment efficacy and treatment failure. Better understanding of the underlying mechanisms of B-ALL could facilitate the development of novel target therapies to reduce the prevalence of B-ALL and the likelihood of relapse.

\section{Pathogenesis}

Lymphoid cells are initially developed from pluripotent hematopoietic stem cells in the bone marrow. B cells are primarily differentiated from common lymphoid progenitor cells pro-B cells, pre-B cells and mature B cells. The maturation process is normally well managed by cell signal transduction, activated transcription factors and positive/negative selection (8). However, in the case of B-ALL, malignancies of B precursor-stage lymphoid cells inhibit lymphoid differentiation, leading to abnormal cell proliferation and survival (9). The occurrence of B-ALL is known to correlate with a series of gene mutations, which often start at the pluripotent stem cell stage, followed by processes of clonal expansion, differentiation, cell proliferation and dysregulated cell apoptosis; the end result is the replacement of normal lymphoid cells by malignant cells (10). A number of molecular pathways and gene expressions are known to be associated with ALL, which are elaborated below.

TEL-AML1. The 'two hits hypothesis' has been proposed to explain the tumorigenesis of childhood ALL (11). Specifically, the TEL-AML1 fusion gene is a mutation that could be present years before any clinical symptom appears, and often the mutation has taken place earlier in utero (12). This oncogene can act on the hematopoietic stem cell (HSC) and produces gene lesions; after the second genetic mutation (or environment hit), the multistep pathway is then activated to develop ALL $(13,14)$. TEL-AML1 is therefore the molecular lesion that initiates the disease; here, the leukemic cells stay at the pro-B-cell stage $(13,14)$. Experiments on cord blood samples are in support of the TEL-AML1 gene mutation occurring in utero $(13,14)$. TEL-AML1-positive subjects have higher risks in developing ALL. TEL-AML1 potentially induces HSC expansion and accelerates transformation (12). Such series of events is consistent with the 'two hits hypothesis' in that two gene mutations are involved for the subsequent development of the malignancy (15).

$B C R-A B L 1$. The ABL gene on chromosome 9 switches location with the BCR gene on chromosome 22 to form the BCR-ABL fusion gene. Chromosome 22 with the new fusion gene is referred to as the Philadelphia chromosome $(\mathrm{Ph})(16)$. The BCR-ABL1 tyrosine kinase gene, transcribed at the $\mathrm{Ph}$ chromosome, is the most common mutation in B-cell ALL. Its worst prognosis is often associated with $\mathrm{Ph}, \mathrm{BCR}-\mathrm{ABL}-1$ positive gene mutation (17). BCR-ABL can promote complex formation of GRB2, GAB2 and Son-of-Sevenless, with subsequent activation of RAS and recruitment of PI3K (18). The activation of RAS triggers signaling pathways of mitogen-activated protein kinase (MAPK) and stimulates cell proliferation. In mediating cell survival and proliferation, PI3K activates its downstream target, the serine-threonine kinase Akt and suppresses the activity of forkhead $\mathrm{O}$ transcriptional factors, degrading p27 and activating mTOR $(19,20)$. To stimulate cell proliferation, BCR-ABL can regulate STAT5 activation, which also enhances cyclin D2 expression through the downregulated expression of miR-93 (21-23).

$P A X 5$. Paired box protein Pax-5 is a $\mathrm{B}$ cell activator protein, which encodes nuclear transcriptional factors. It modulates $\mathrm{B}$ cell functions, including development, differentiation, migration and proliferation (24). Pax-5 controls B cell development from pro to mature B cells. Abnormal expressions of Pax-5 can lead to leukemic transformation at the early stage of tumorigenesis in B-ALL (25). The development of pro B cells is arrested under downregulated Pax-5 expression, an evidence in support of the critical role of Pax-5 on B cell development. Over $90 \%$ pediatric patients with B-ALL have overexpressed Pax-5 (24). Pax-5 can fuse with other proteins, such as Janus kinase (Jak) 2, to create an active kinase domain, leading to B cell proliferation via the Jak-STAT signaling pathways (26).

$R A S$. Patients with ALL and poor prognosis or relapses often have mutations in the RAS pathways; these mutations frequently occur during chemotherapy and are present in clones of relapsed leukemic cells (27). A recent study sequenced 13 RAS pathway genes derived from 461 initially diagnosed pediatric patients with B cell precursor-ALL and reported that $44.2 \%$ of patients displayed mutations in their RAS pathways (28). Such RAS mutations are also present in $\sim 40 \%$ of relapsed pediatric patients with ALL (27). The activation of RAS pathways in leukemic cells impairs the efficacy of medical therapy using drugs such as glucocorticoids or anthracycline $(29,30)$. HSC cells with RAS gene mutations show uncontrolled growth (31). Approximately $15 \%$ of pediatric patients with ALL have mutations on both NRAS and KRAS genes. These mutations, however, show no correlation with any other clinical symptom $(32,33)$.

$P I 3 K$. The PI3K/Akt signaling pathway is involved in cell proliferation and cell survival. PI3K regulates the expression levels of mTOR, Bcl-2, NFKB and other proteins that all promote cell proliferation $(34,35)$. The PI3K/Akt signaling pathway is activated in various types of liquid tumors such as B cell precursor-ALL (36) and hence it serves an important role in pathogenesis (37). In the leukemia microenvironment, marrow stromal cells (MSCs) promote the proliferation of leukemic cells and strengthen their resistance to chemotherapy, through PI3K/Akt signaling pathway (38). MSCs secrete $\mathrm{C}-\mathrm{X}-\mathrm{C}$ motif chemokine 12 that acts on $\mathrm{C}-\mathrm{X}-\mathrm{C}$ chemokine receptor type 4 of the leukemia blast cells and through the PI3K and Wnt pathways exert influences on their survival and proliferation (39). Overactivated PI3K pathway is frequently found in B-ALL and such overactivation is also associated with glucocorticoid resistance (40). Patients with B-ALL bearing negative regulators of the PI3E mutation, such as phosphatase and tensin homolog (PTEN), may have a higher chance of treatment failure and relapse (41). 
Cell cycle. Deregulated cell cycles are correlated with the development of B-ALL (42). Uncontrolled proliferation of HSC and immature lymphoblastic cells can lead to leukemogenesis (43). Overexpression of c-MYC protein is associated with accelerated cell cycle progression in B-ALL (44). The dysregulation of c-MYC occurs in aggressive B-ALL cases and is correlated with aggressive course of disease, chemoresistance and poor prognosis $(45,46)$. Autophagy inhibitor is found to inhibit B-ALL proliferation through arrested cell cycle at the G2/M phase (6), which indicates that autophagy in B-ALL potentially expedites cell cycle, and hence autophagy represents a novel therapeutic target for treating B-ALL (6). In addition, an elevated expression of nucleophosmin (NPM) is associated with the pathogenesis of acute leukemia. NPM, which plays an important role on cell proliferation, is commonly found in actively proliferating cells. NPM synthesis begins at $\mathrm{G}_{1}$ phase and after its phosphorylation at both the Ser10 and Ser70 sites, cell cycle enters $\mathrm{G}_{2} / \mathrm{M}$ phase, via the modulations of $\mathrm{Cdk} 1$ and Cdc25C (47).

\section{Risk factors}

Viral infection. One mechanism of leukemogenesis is DNA methylation caused by viral infections (48). The abnormal expression of hematopoietic and proliferation genes persists even after viral clearance. Patients with ALL with an infection history of parvovirus B19 show abnormal DNA methylation (49). Genes associated with cell proliferation and patterns of DNA methylation can be altered by ordinary infections and subsequently lead to altered progression of the ALL disease (50).

High birth weight. The progression of pediatric ALL can start in utero or shortly after birth. Rapid growth of the fetus increases the risk of inflicting ALL (51). High birth weight is an important risk factor for pediatric ALL $(52,53)$. Similarly, gene expression of the insulin growth factor (IGF) axis also serves an important role; this abnormal gene expression can start in utero or during the early postnatal period when lymphoid stem cells are immature, and therefore increasing the risk of malignant transformation (3). The key regulators of fetal growth are IGF1, IGF2 and their receptors, IGF1R, IGF2R (54). During the postnatal period, IGF1 continues its influence on growth (55). Susceptive genotype of IGF1 is a high risk factor for childhood ALL in both the Hispanic and non-Hispanic populations, while IGF2 expression affects only the Hispanic population (3).

Environmental toxins. Benzene is widely present in the work environment, such as in fumes of paint and cigarette smoke. Benzene is a known carcinogen and parental exposure to benzene increases the risk of childhood ALL (56). In the liver or lung, benzene is metabolized to benzene oxide and hydroquinone, before further converted to benzoquinone in the bone marrow, where cytotoxicity and DNA damages typically occur (57). Prolonged DNA damages in the bone marrow increases the risk of developing ALL (58). A recent study reported that avoiding exposures to occupational and environmental benzene during pregnancy lowers the risk of ALL in the offspring (59).

\section{Treatments}

Currently, for childhood B-ALL, risk-directed therapy is the standard treatment. The age of the child at diagnosis is taken into account. Other factors considered are the initial white blood cell count, immunophenotypic and cytogenetic characteristics of the blast population, as well as the rapidity of response to early treatment. Standard treatment consists of chemotherapy that lasts 2-3 years. For many patients, complete remission (CR) is achieved at the end of the induction phase (60).

The success of such treatment involves a multidrug regimen that consists of three phases (induction, consolidation and maintenance), during which therapy or prophylaxis directed to the central nervous system (CNS) is delivered in multiple sessions (61).

The primary goal of induction is to reach an initial CR and to restore normal hematopoiesis. Induction therapy involves a weekly medication of vincristine and anthracycline for 3-4 weeks, daily corticosteroids and asparaginase (62).

The routine use of preventive CNS therapy is a major therapeutic advancement in the treatment of childhood ALL. CNS treatment usually begins in the induction phase and lasts until the end of treatment regimen. In some CNS preventive therapy protocols, the craniospinal radiotherapy is replaced by intrathecal chemotherapy (63).

The second phase of treatment, or consolidation, is focused on intensive CNS therapy in combination with sustained intensive systemic therapy. This phase of treatment starts shortly after the patient has reached CR. The goal of consolidation chemotherapy is to prevent leukemic regrowth, reduce residual tumor burden and prevent the emergence of drug-resistance in other leukemic cells (64). A combination of several drugs is typically involved with pharmacological mechanisms that are different from those in the induction phase; regimens often include the following drugs: Cytarabine, methotrexate, anthracyclines and alkylating agents (65-67). These drugs are administered according to schedules that would maximize drug synergy and minimize drug resistance.

After completing the consolidation (or intensification) phase of therapy, patients will often receive a less intensive continuation regimen (maintenance chemotherapy) that involves daily oral 6-mercaptopurine, weekly methotrexate with periodic vincristine, corticosteroid and intrathecal therapy. Maintenance phase lasts for another 2-3 years. Extending the maintenance phase thereafter has little benefits $(68,69)$.

Approximately $15 \%$ of patients would relapse after treatment and the overall survival of patients with relapse is $<10 \%$ (70). Thus, it is important to develop new ALL treatment strategies that have higher CR and lower drug toxicity. In recent years, resveratrol has been reported to induce apoptosis, cell cycle arrest or decrease cell proliferation through the enhanced expressions of p21 and p27 (71). The reduced expressions of antiapoptotic proteins, myeloid cell leukemia 1 and $\mathrm{Bcl}-2$ and increased expressions of proapoptotic proteins, Bax, Bcl-2-like protein 11 and Bad, have resulted in upregulating caspase 3 (72). In addition, everolimus is an mTOR inhibitor, which induces autophagy and promotes cell death (73). This drug induces apoptosis through caspase-independent pathways and alters the mitochondrial permeability, 


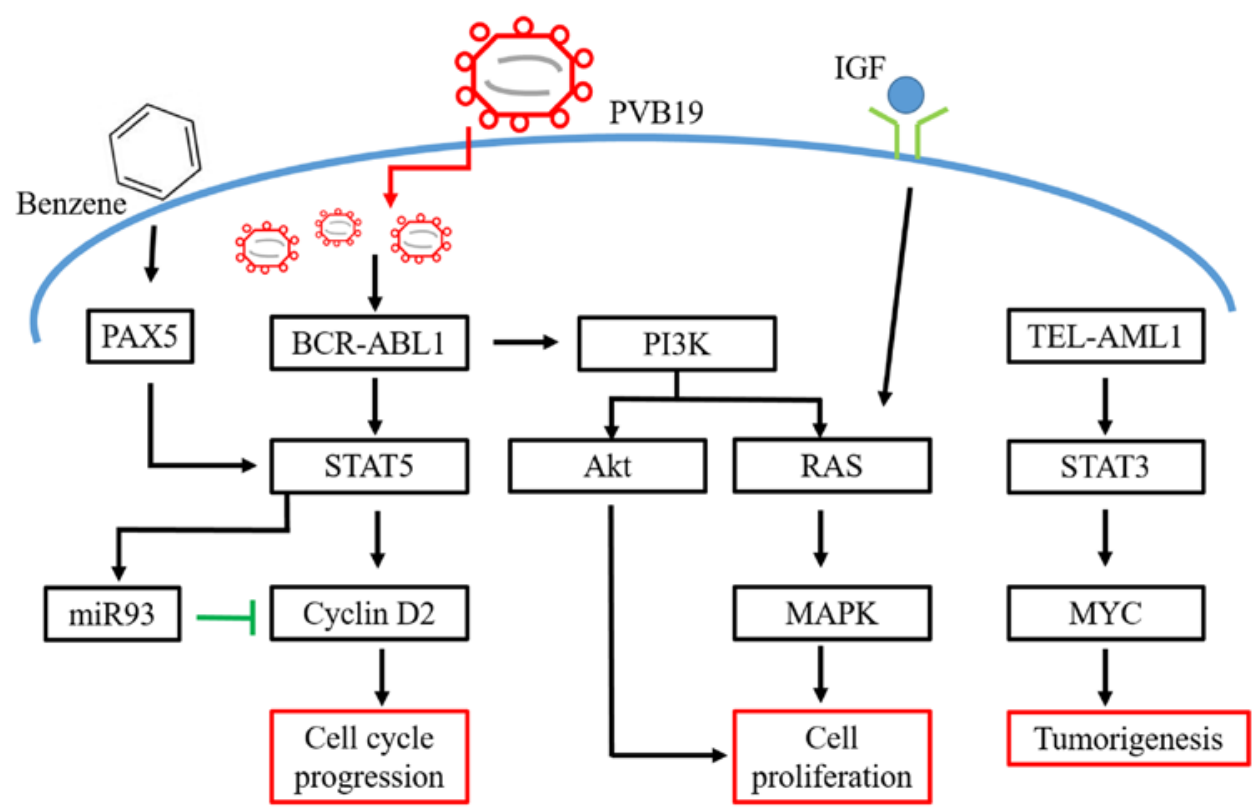

Figure 1. Schematic diagram of pathogenesis and risk factors in acute lymphoblastic leukemia. PVB 19: Parvovirus B19; IGF, insulin growth factor; miR, microRNA.

leading to cell dysfunction (70). Everolimus kills malignant cells through paraptosis (70). A specific inhibitor of mitogen activated protein kinase (MEK), selumetinib, could treat ALL. It acts on MEK1/2 to inhibit ERK-dependent cell proliferation (74). This drug has been used to treat RAS-mutated ALL with good results in vitro and in vivo $(27,75)$. Besides these aforementioned target therapies, other new strategies to treat ALL are outlined below.

Autophagy-targeting treatment. Autophagy is the process of breaking down intracellular organelles for energy transfer to maintain homeostasis compatible with cell viability. The process of autophagy is switched on when cells are stressed or damaged to a certain degree. Leukemic cells resistant to chemotherapy are found to have activated autophagy (76). Thus, targeting autophagy is a promising new therapeutic approach to treat B-ALL. In models of ALL cell line, newly developed drugs produce autophagy, cell cycle arrest and apoptosis. However, after combined treatment with autophagy inhibitor, cell viability is often downregulated. Results indicate that autophagy protects leukemic cells against cytotoxicity caused by anti-cancer drugs $(77,78)$. This approach of autophagy manipulation might be an alternative for ALL treatment.

$c$-Myb-targeted therapy. c-Myb is the protein product of a proto-oncogene. It has three domains: N-terminal DNA binding domain, central transcriptional activation domain and C-terminal domain (79). The gene is carried by the avian myeloblastosis virus and the E26 retrovirus (80). During proliferation, especially of immature cells, the c-Myb transcription factor is overexpressed (81). In leukemia animal models and in vitro systems, c-Myb inhibitors delay disease onset (2). Inhibition of c-Myb downregulates leukemic cell proliferation, increases G0/G1 arrest and increases sensitivity of pre-B-ALL cells to cytotoxic agents $(82,83)$. Experimental evidence is in support of c-Myb being a potential target for immunotherapy of ALL (83). Furthermore, other tumor cells also express $\mathrm{c}-\mathrm{Myb}$, making c-Myb-targeting therapy promising in clinical practice (84).

\section{Monitoring treatment efficacy}

It is important to evaluate treatment efficacy of any ALL therapy. Apart from the traditional blood test, the levels of microRNA and soluble interleukin receptors are used to monitor the treatment efficacy $(85,86)$. In a whole genome microRNA analysis on patients with ALL, dysregulated expression of miR-128, miR-146a, miR-155, miR-181a and miR-195 were found (87). Treatments lasting for 6 months resulted in downregulated expressions of miR-146a, miR-155, miR-181a and miR-195 (87). Soluble interleukin 2 receptor (sIL-2R) has been identified as a biomarker of the disease activity of non-Hodgkin's lymphoma and it also reflects the tumor volume (88). Increased expression of sIL-2R are present in other lymphoproliferative disorders such as chronic lymphocytic leukemia and ALL. Immature blast cells release sIL-2R before entering the blood stream (89). Therefore, sIL-2R is useful for monitoring the treatment efficacy of ALL.

\section{Treatment failure}

For B-ALL patients, the frequency of relapse is associated with multiple drug resistance (MDR) (90). The overexpression of drug efflux pumps on leukemic cells under drug treatment is the most common condition for MDR and consequently the intracellular drug concentration is lowered (91). ATP-binding cassette (ABC) transporters actively pump drugs out of cells and their expression level is regulated by a number of intracellular signaling pathways, including MAPK, ERK and JNK $(92,93)$. The ABC transporter pump is encoded by genes including $\mathrm{ABCB} 1, \mathrm{ABCC} 1$ and $\mathrm{ABCG} 2$. 
Higher expression of $\mathrm{ABCB} 1$ gene has been reported in ALL cell lines and higher expression of ABCB1 is known to associate with poorer prognosis and shorter disease-free survival rates $(94,95)$. Another mechanism of MDR concerns glutathione (GSH) and its associated enzymes, which are a part of the cell defense system against chemodrug-induced reactive oxygen species stress $(96,97)$. Glutathione reductase is the key enzyme of the GSH redox cycle and it reduces the sensitivity to chemodrugs in leukemic cells by modulating redox homeostasis (98).

\section{Conclusion}

B-ALL is the most prevalent cancer in children. Despite better cure rates in recent years, the disease will still relapse for some patients. Therefore, understanding the molecular pathways for the pathophysiology of B-ALL and its relapse mechanisms are important (Fig. 1). Not all patients with B-ALL have satisfactory outcomes under the current treatments. Newly developed immune-targeting therapy would probably enhance the efficacy of chemotherapy and improve prognosis. Biomarkers can be used to monitor treatment course and to provide information for drug and dose adjustments. Well-designed clinical trials should be conducted to gain insights for constructing more effective immune targeting therapies and treatment protocols.

\section{Acknowledgements}

Not applicable.

\section{Funding}

The present work was supported by a grant from Taichung Veterans General Hospital (grant no. TCVGH-NCHU1097611; Taichung, Taiwan, R.O.C.).

\section{Availability of data and materials}

Not applicable.

\section{Authors' contributions}

FLH, CYY and SJY drafted the manuscript. ECL and CLL were involved in literature review and revising the manuscript. CYY and SJY edited the manuscript and were involved in the conception and design of this review article. All authors read and approved the final manuscript.

\section{Ethics approval and consent to participate}

Not applicable.

\section{Patient consent for publication}

Not applicable.

\section{Competing interests}

The authors declare that they have no competing interests.

\section{References}

1. Shafat MS, Gnaneswaran B, Bowles KM and Rushworth SA: The bone marrow microenvironment-Home of the leukemic blasts. Blood Rev 31: 277-286, 2017.

2. Sarvaiya PJ, Schwartz JR, Hernandez CP, Rodriguez PC and Vedeckis WV: Role of c-Myb in the survival of pre B-cell acute lymphoblastic leukemia and leukemogenesis. Am J Hematol 87: 969-976, 2012.

3. Chokkalingam AP, Metayer C, Scelo G, Chang JS, Schiffman J, Urayama KY, Ma X, Hansen HM, Feusner JH, Barcellos LF, et al: Fetal growth and body size genes and risk of childhood acute lymphoblastic leukemia. Cancer Causes Control 23: 1577-1585, 2012.

4. Liu YF, Wang BY, Zhang WN, Huang JY, Li BS, Zhang M, Jiang L, Li JF, Wang MJ, Dai YJ, et al: Genomic profiling of adult and pediatric B-cell acute lymphoblastic leukemia. EBioMedicine 8: 173-183, 2016.

5. Consolaro F, Basso G, Ghaem-Magami S, Lam EW and Viola G: FOXM1 is overexpressed in B-acute lymphoblastic leukemia (B-ALL) and its inhibition sensitizes B-ALL cells to chemotherapeutic drugs. Int J Oncol 47: 1230-1240, 2015.

6. Wang Z, Zhu S, Zhang G and Liu S: Inhibition of autophagy enhances the anticancer activity of bortezomib in B-cell acute lymphoblastic leukemia cells. Am J Cancer Res 5: 639-650, 2015.

7. Tran TH, Harris MH, Nguyen JV, Blonquist TM, Stevenson KE, Stonerock E, Asselin BL, Athale UH, Clavell LA, Cole PD, et al: Prognostic impact of kinase-activating fusions and IKZF1 deletions in pediatric high-risk B-lineage acute lymphoblastic leukemia. Blood Adv 2: 529-533, 2018.

8. Zhou Y, You MJ, Young KH, Lin P, Lu G, Medeiros LJ and Bueso-Ramos CE: Advances in the molecular pathobiology of B-lymphoblastic leukemia. Hum Pathol 43: 1347-1362, 2012.

9. Zuckerman T and Rowe JM: Pathogenesis and prognostication in acute lymphoblastic leukemia. F1000Prime Rep 6: 59, 2014.

10. Bowman RL, Busque L and Levine RL: Clonal hematopoiesis and evolution to hematopoietic malignancies. Cell Stem Cell 22: 157-170, 2018.

11. Morales-Sánchez A and Fuentes-Panana EM: Infectious etiology of childhood acute lymphoblastic leukemia, hypotheses and evidence. In: Clinical Epidemiology of Acute Lymphoblastic Leukemia: From the Molecules to the Clinic. Mejia-Arangure JM (ed) InTech Rijeka, Croatia, pp19-39, 2013.

12. Schindler JW, Van Buren D, Foudi A, Krejci O, Qin J, Orkin SH and Hock H: TEL-AML1 corrupts hematopoietic stem cells to persist in the bone marrow and initiate leukemia. Cell Stem Cell 5: 43-53, 2009.

13. Ford AM, Bennett CA, Price CM, Bruin MC, Van Wering ER and Greaves M: Fetal origins of the TEL-AML1 fusion gene in identical twins with leukemia. Proc Natl Acad Sci USA 95: 4584-4588, 1998.

14. Sabaawy HE, Azuma M, Embree LJ, Tsai HJ, Starost MF and Hickstein DD: TEL-AML1 transgenic zebrafish model of precursor B cell acute lymphoblastic leukemia. Proc Natl Acad Sci USA 103: 15166-15171, 2006.

15. Jan M and Majeti R: Clonal evolution of acute leukemia genomes. Oncogene 32: 135-140, 2013.

16. El Fakih R, Jabbour E, Ravandi F, Hassanein M, Anjum F, Ahmed S and Kantarjian H: Current paradigms in the management of Philadelphia chromosome positive acute lymphoblastic leukemia in adults. Am J Hematol 93: 286-295, 2018.

17. Thomas DA, Faderl S, Cortes J, O'Brien S, Giles FJ, Kornblau SM, Garcia-Manero G, Keating MJ, Andreeff M, Jeha S, et al: Treatment of Philadelphia chromosome-positive acute lymphocytic leukemia with hyper-CVAD and imatinib mesylate. Blood 103: 4396-4407, 2004.

18. Cilloni D and Saglio G: Molecular pathways: BCR-ABL. Clin Cancer Res 18: 930-937, 2012.

19. Ho WC, Pikor L, Gao Y, Elliott BE and Greer PA: Calpain 2 regulates Akt-FoxO-p27(Kip1) protein signaling pathway in mammary carcinoma. J Biol Chem 287: 15458-15465, 2012.

20. Mantamadiotis T: Towards targeting PI3K-dependent regulation of gene expression in brain cancer. Cancers (Basel) 9: pii: E60, 2017.

21. Schotte D, De Menezes RX, Akbari Moqadam F, Khankahdani LM, Lange-Turenhout E, Chen C, Pieters R and Den Boer ML: MicroRNA characterize genetic diversity and drug resistance in pediatric acute lymphoblastic leukemia. Haematologica 96: 703-711, 2011. 
22. Deininger MW, Vieira SA, Parada Y, Banerji L, Lam EW, Peters G, Mahon FX, Köhler T, Goldman JM and Melo JV: Direct relation between BCR-ABL tyrosine kinase activity and cyclin D2 expression in lymphoblasts. Cancer Res 61: 8005-8013, 2001.

23. Parada Y, Banerji L, Glassford J, Lea NC, Collado M, Rivas C, Lewis JL, Gordon MY, Thomas NS and Lam EW: BCR-ABL and interleukin 3 promote haematopoietic cell proliferation and survival through modulation of cyclin D2 and p27Kip1 expression. J Biol Chem 276: 23572-23580, 2001.

24. Firtina S, Sayitoglu M, Hatirnaz O, Erbilgin Y, Oztunc C, Cinar S, Yildiz I, Celkan T, Anak S, Unuvar A, et al: Evaluation of PAX5 gene in the early stages of leukemic B cells in the childhood B cell acute lymphoblastic leukemia. Leuk Res 36: 87-92, 2012.

25. Tiacci E, Pileri S, Orleth A, Pacini R, Tabarrini A, Frenguelli F, Liso A, Diverio D, Lo-Coco F and Falini B: PAX5 expression in acute leukemias: higher B-lineage specificity than CD79a and selective association with $\mathrm{t}(8 ; 21)$-acute myelogenous leukemia. Cancer Res 64: 7399-7404, 2004.

26. Schinnerl D, Fortschegger K, Kauer M, Marchante JR, Kofler R, Den Boer ML and Strehl S: The role of the Janus-faced transcription factor PAX5-JAK2 in acute lymphoblastic leukemia. Blood 125: 1282-1291, 2015.

27. Irving J, Matheson E, Minto L, Blair H, Case M, Halsey C, Swidenbank I, Ponthan F, Kirschner-Schwabe R, Groeneveld-Krentz S, et al: Ras pathway mutations are prevalent in relapsed childhood acute lymphoblastic leukemia and confer sensitivity to MEK inhibition. Blood 124: 3420-3430, 2014.

28. Jerchel IS, Hoogkamer AQ, Ariës IM, Steeghs EMP, Boer JM, Besselink NJM, Boeree A, van de Ven C, de Groot-Kruseman HA, de Haas V, et al: RAS pathway mutations as a predictive biomarker for treatment adaptation in pediatric B-cell precursor acute lymphoblastic leukemia. Leukemia 32: 931-940, 2018.

29. Jones CL, Gearheart CM, Fosmire S, Delgado-Martin C, Evensen NA, Bride K, Waanders AJ, Pais F, Wang J, Bhatla T, et al: MAPK signaling cascades mediate distinct glucocorticoid resistance mechanisms in pediatric leukemia. Blood 126: 2202-2212, 2015.

30. McCubrey JA, Steelman LS, Chappell WH, Abrams SL, Wong EW, Chang F, Lehmann B, Terrian DM, Milella M, Tafuri A, et al: Roles of the Raf/MEK/ERK pathway in cell growth, malignant transformation and drug resistance. Biochim Biophys Acta 1773: 1263-1284, 2007.

31. Zhang J, Wang J, Liu Y, Sidik H, Young KH, Lodish HF and Fleming MD: Oncogenic Kras-induced leukemogeneis: Hematopoietic stem cells as the initial target and lineage-specific progenitors as the potential targets for final leukemic transformation. Blood 113: 1304-1314, 2009.

32. Shu XO, Perentesis JP, Wen W, Buckley JD, Boyle E, Ross JA and Robison LL; Children's Oncology Group: Parental exposure to medications and hydrocarbons and ras mutations in children with acute lymphoblastic leukemia: A report from the Children's Oncology Group. Cancer Epidemiol Biomarkers Prev 13: 1230-1235, 2004.

33. Al-Kzayer LF, Sakashita K, Al-Jadiry MF, Al-Hadad SA, Ghali HH, Uyen Le TN, Liu T, Matsuda K, Abdulkadhim JM, Al-Shujairi TA, et al: Analysis of KRAS and NRAS Gene Mutations in Arab Asian Children With Acute Leukemia: High Frequency of RAS Mutations in Acute Lymphoblastic Leukemia. Pediatr Blood Cancer 62: 2157-2161, 2015.

34. Li H, Zeng J and Shen K: PI3K/AKT/mTOR signaling pathway as a therapeutic target for ovarian cancer. Arch Gynecol Obstet 290 1067-1078, 2014

35. Wu MH, Lee TH, Lee HP, Li TM, Lee IT, Shieh PC and Tang CH: Kuei-Lu-Er-Xian-Jiao extract enhances BMP-2 production in osteoblasts. Biomedicine (Taipei) 7: 2, 2017.

36. Toosi B, Zaker F, Alikarami F, Kazemi A and Teremmahi Ardestanii M: VS-5584 as a PI3K/mTOR inhibitor enhances apoptotic effects of subtoxic dose arsenic trioxide via inhibition of NF- $\kappa \mathrm{B}$ activity in B cell precursor-acute lymphoblastic leukemia. Biomed Pharmacother 102: 428-437, 2018.

37. Morishita N, Tsukahara H, Chayama K, Ishida T, Washio K, Miyamura T, Yamashita N, Oda M and Morishima T: Activation of Akt is associated with poor prognosis and chemotherapeutic resistance in pediatric B-precursor acute lymphoblastic leukemia. Pediatr Blood Cancer 59: 83-89, 2012.

38. Sanchez VE, Nichols C, Kim HN, Gang EJ and Kim YM Targeting PI3K signaling in acute lymphoblastic leukemia. Int J Mol Sci 20: pii: E412, 2019.
39. Yang Y, Mallampati S, Sun B, Zhang J, Kim SB, Lee JS, Gong Y, Cai Z and Sun X: Wnt pathway contributes to the protection by bone marrow stromal cells of acute lymphoblastic leukemia cells and is a potential therapeutic target. Cancer Lett 333: 9-17, 2013.

40. Evangelisti C, Cappellini A, Oliveira M, Fragoso R, Barata JT, Bertaina A, Locatelli F, Simioni C, Neri LM, Chiarini F, et al: Phosphatidylinositol 3-kinase inhibition potentiates glucocorticoid response in B-cell acute lymphoblastic leukemia. J Cell Physiol 233: 1796-1811, 2018.

41. Silveira AB, Laranjeira AB, Rodrigues GO, Leal PC, Cardoso BA, Barata JT, Yunes RA, Zanchin NI, Brandalise SR and Yunes JA: PI3K inhibition synergizes with glucocorticoids but antagonizes with methotrexate in T-cell acute lymphoblastic leukemia. Oncotarget 6: 13105-13118, 2015.

42. Sánchez-Beato M, Sánchez-Aguilera A and Piris MA: Cell cycle deregulation in B-cell lymphomas. Blood 101: 1220-1235, 2003.

43. Huang MM and Zhu J: The regulation of normal and leukemic hematopoietic stem cells by niches. Cancer Microenviron 5: 295-305, 2012.

44. Yang Y, Xue K, Li Z, Zheng W, Dong W, Song J, Sun S, Ma T and Li W: c-Myc regulates the CDK1/cyclin B1 dependentG2/M cell cycle progression by histone $\mathrm{H} 4$ acetylation in Raji cells. Int J Mol Med 41: 3366-3378, 2018.

45. Ren Y, Bi C, Zhao X, Lwin T, Wang C, Yuan J, Silva AS, Shah BD, Fang B, Li T, et al: PLK1 stabilizes a MYC-dependent kinase network in aggressive B cell lymphomas. J Clin Invest 128: 5517-5530, 2018

46. Slack GW and Gascoyne RD: MYC and aggressive B-cell lymphomas. Adv Anat Pathol 18: 219-228, 2011.

47. Du W, Zhou Y, Pike S and Pang Q: NPM phosphorylation stimulates Cdk1, overrides G2/M checkpoint and increases leukemic blasts in mice. Carcinogenesis 31: 302-310, 2010.

48. Rahmani M, Talebi M, Hagh MF, Feizi AAH and Solali S: Aberrant DNA methylation of key genes and Acute Lymphoblastic Leukemia. Biomed Pharmacother 97: 1493-1500, 2018.

49. Vasconcelos GM, Christensen BC, Houseman EA, Xiao J, Marsit CJ, Wiencke JK, Zheng S, Karagas MR, Nelson HH, Wrensch MR, et al: History of Parvovirus B19 infection is associated with a DNA methylation signature in childhood acute lymphoblastic leukemia. Epigenetics 6: 1436-1443, 2011.

50. Timms JA, Relton CL, Rankin J, Strathdee G and McKay JA: DNA methylation as a potential mediator of environmental risks in the development of childhood acute lymphoblastic leukemia. Epigenomics 8: 519-536, 2016.

51. Milne E, Laurvick CL, Blair E, Bower C and de Klerk N: Fetal growth and acute childhood leukemia: Looking beyond birth weight. Am J Epidemiol 166: 151-159, 2007.

52. Groves FD, Watkins BT, Roberts DJ, Tucker TC, Shen T and Flood TJ: Birth weight and risk of childhood acute lymphoblastic leukemia in arizona, Illinois, and kentucky. South Med J 111: 579-584, 2018

53. Robison LL, Codd M, Gunderson P, Neglia JP, Smithson WA and King FL: Birth weight as a risk factor for childhood acute lymphoblastic leukemia. Pediatr Hematol Oncol 4: 63-72, 1987.

54. Hellström A, Ley D, Hansen-Pupp I, Hallberg B, Ramenghi LA, Löfqvist C, Smith LE and Hard AL: Role of insulinlike growth factor 1 in fetal development and in the early postnatal life of premature infants. Am J Perinatol 33: 1067-1071, 2016.

55. Stratikopoulos E, Szabolcs M, Dragatsis I, Klinakis A and Efstratiadis A: The hormonal action of IGF1 in postnatal mouse growth. Proc Natl Acad Sci USA 105: 19378-19383, 2008.

56. Khalade A, Jaakkola MS, Pukkala E and Jaakkola JJ: Exposure to benzene at work and the risk of leukemia: A systematic review and meta-analysis. Environ Health 9: 31, 2010.

57. Xie Z, Zhang Y, Guliaev AB, Shen H, Hang B, Singer B and Wang Z: The p-benzoquinone DNA adducts derived from benzene are highly mutagenic. DNA Repair (Amst) 4: 1399-1409, 2005.

58. Mansell E, Zareian N, Malouf C, Kapeni C, Brown N, Badie C, Baird D, Lane J, Ottersbach K, Blair A and Case CP: DNA damage signalling from the placenta to foetal blood as a potential mechanism for childhood leukaemia initiation. Sci Rep 9: 4370, 2019.

59. Zhou Y, Zhang S, Li Z, Zhu J, Bi Y, Bai Y and Wang H: Maternal benzene exposure during pregnancy and risk of childhood acute lymphoblastic leukemia: A meta-analysis of epidemiologic studies. PLoS One 9: e110466, 2014.

60. Cooper SL and Brown PA: Treatment of pediatric acute lymphoblastic leukemia. Pediatr Clin North Am 62: 61-73, 2015. 
61. Pui CH, Campana D, Pei D, Bowman WP, Sandlund JT, Kaste SC, Ribeiro RC, Rubnitz JE, Raimondi SC, Onciu M, et al: Treating childhood acute lymphoblastic leukemia without cranial irradiation. N Engl J Med 360: 2730-2741, 2009.

62. Tsurusawa M, Shimomura Y, Asami K, Kikuta A, Watanabe A, Horikoshi Y, Matsushita T, Kanegane H, Ohta S, Iwai A, et al: Long-term results of the Japanese childhood cancer and leukemia study group studies $811,841,874$ and 911 on childhood acute lymphoblastic leukemia. Leukemia 24: 335-344, 2010.

63. Pui CH, Pei D, Sandlund JT, Ribeiro RC, Rubnitz JE, Raimondi SC, Onciu M, Campana D, Kun LE, Jeha S, et al: Long-term results of St Jude total therapy studies 11, 12, 13A $13 \mathrm{~B}$, and 14 for childhood acute lymphoblastic leukemia. Leukemia 24: 371-382, 2010.

64. Jabbour EJ, Faderl S and Kantarjian HM: Adult acute lymphoblastic leukemia. Mayo Clin Proc 80: 1517-1527, 2005.

65. Winter SS, Holdsworth MT, Devidas M, Raisch DW, Chauvenet A, Ravindranath Y, Ducore JM and Amylon MD: Antimetabolite-based therapy in childhood T-cell acute lymphoblastic leukemia: A report of POG study 9296. Pediatr Blood Cancer 46: 179-186, 2006.

66. Seymour JF, Grigg AP, Szer J and Fox RM: Cisplatin, fludarabine, and cytarabine: A novel, pharmacologically designed salvage therapy for patients with refractory, histologically aggressive or mantle cell non-Hodgkin's lymphoma. Cancer 94: $585-593,2002$

67. Kato $\mathrm{M}$ and Manabe A: Treatment and biology of pediatric acute lymphoblastic leukemia. Pediatr Int 60: 4-12, 2018.

68. Narayanan S and Shami PJ: Treatment of acute lymphoblastic leukemia in adults. Crit Rev Oncol Hematol 81: 94-102, 2012.

69. Terwilliger T and Abdul-Hay M: Acute lymphoblastic leukemia: A comprehensive review and 2017 update. Blood Cancer J 7: e577, 2017.

70. Baraz R, Cisterne A, Saunders PO, Hewson J, Thien M, Weiss J, Basnett J, Bradstock KF and Bendall LJ: mTOR inhibition by everolimus in childhood acute lymphoblastic leukemia induces caspase-independent cell death. PLoS One 9: e102494, 2014.

71. Singh SK, Banerjee S, Acosta EP, Lillard JW and Singh R: Resveratrol induces cell cycle arrest and apoptosis with docetaxe in prostate cancer cells via a p53/p21WAF1/CIP1 and p27KIP1 pathway. Oncotarget 8: 17216-17228, 2017.

72. Ge J, Liu Y, Li Q, Guo X, Gu L, Ma ZG and Zhu YP: Resveratrol induces apoptosis and autophagy in T-cell acute lymphoblastic leukemia cells by inhibiting Akt/mTOR and activating p38-MAPK. Biomed Environ Sci 26: 902-911, 2013.

73. Cai Y, Xia Q, Su Q, Luo R, Sun Y, Shi Y and Jiang W: mTOR inhibitor RAD001 (Everolimus) induces apoptotic, not autophagic cell death, in human nasopharyngeal carcinoma cells. Int J Mol Med 31: 904-912, 2013.

74. Ciombor KK and Bekaii-Saab T: Selumetinib for the treatment of cancer. Expert Opin Investig Drugs 24: 111-123, 2015.

75. Kerstjens M, Driessen EM, Willekes M, Pinhancos SS Schneider P, Pieters R and Stam RW: MEK inhibition is a promising therapeutic strategy for MLL-rearranged infant acute lymphoblastic leukemia patients carrying RAS mutations. Oncotarget 8: 14835-14846, 2017.

76. Piya S, Andreeff M and Borthakur G: Targeting autophagy to overcome chemoresistance in acute myleogenous leukemia. Autophagy 13: 214-215, 2017.

77. Takahashi H, Inoue J, Sakaguchi K, Takagi M, Mizutani S and Inazawa J: Autophagy is required for cell survival under L-asparaginase-induced metabolic stress in acute lymphoblastic leukemia cells. Oncogene 36: 4267-4276, 2017.

78. Takahashi H, Inoue J, Sakaguchi K, Takagi M, Mizutani S and Inazawa J: Autophagy inhibition sensitizes acute lymphoblastic leukemia cells to L-asparaginase. Blood 126: 3772-3772, 2015.

79. Sakura H, Kanei-Ishii C, Nagase T, Nakagoshi H, Gonda TJ and Ishii S: Delineation of three functional domains of the transcriptional activator encoded by the c-myb protooncogene. Proc Natl Acad Sci USA 86: 5758-5762, 1989

80. Tanaka $\mathrm{Y}$, Nomura $\mathrm{T}$ and Ishii S: Two regions in c-myb proto-oncogene product negatively regulating its DNA-binding activity. FEBS Lett 413: 162-168, 1997.
81. Zhou Y and Ness SA: Myb proteins: Angels and demons in normal and transformed cells. Front Biosci (Landmark Ed) 16: 1109-1131, 2011.

82. Lv M, Wang Y, Wu W, Yang S, Zhu H, Hu B, Chen Y, Shi C, Zhang Y, Mu Q and Ouyang G: CMyc inhibitor 10058F4 increases the efficacy of dexamethasone on acute lymphoblastic leukaemia cells. Mol Med Rep 18: 421-428, 2018.

83. Liu X, Xu Y, Han L and Yi Y: Reassessing the Potential of Myb-targeted Anti-cancer Therapy. J Cancer 9: 1259-1266, 2018.

84. Mitra P: Transcription regulation of MYB: A potential and novel therapeutic target in cancer. Ann Transl Med 6: 443, 2018.

85. Grobbelaar C and Ford AM: The Role of MicroRNA in paediatric acute lymphoblastic leukaemia: Challenges for diagnosis and therapy. J Oncol 2019: 8941471, 2019.

86. Nakase K, Kita K, Miwa H, Nishii K, Shikami M, Tanaka I, Tsutani H, Ueda T, Nasu K, Kyo T, et al: Clinical and prognostic significance of cytokine receptor expression in adult acute lymphoblastic leukemia: Interleukin-2 receptor alpha-chain predicts a poor prognosis. Leukemia 21: 326-332, 2007.

87. Duyu M, Durmaz B, Gunduz C, Vergin C, Yilmaz Karapinar D, Aksoylar S, Kavakli K, Cetingul N, Irken G, Yaman Y, et al: Prospective evaluation of whole genome microRNA expression profiling in childhood acute lymphoblastic leukemia. Biomed Res Int 2014: 967585, 2014.

88. Yoshida N, Oda M, Kuroda Y, Katayama Y, Okikawa Y, Masunari T, Fujiwara M, Nishisaka T, Sasaki N, Sadahira Y, et al: Clinical significance of sIL-2R levels in B-cell lymphomas. PLoS One 8: e78730, 2013.

89. Nakase K, Kita K, Kyo T, Tsuji K and Katayama N: High serum levels of soluble interleukin-2 receptor in acute myeloid leukemia: Correlation with poor prognosis and CD4 expression on blast cells. Cancer Epidemiol 36: e306-e309, 2012.

90. Li B, Brady SW, Ma X, Shen S, Zhang Y, Li Y, Szlachta K, Dong L, Liu Y, Yang F, et al: Therapy-induced mutations drive the genomic landscape of relapsed acute lymphoblastic leukemia. Blood 135: 41-55, 2020.

91. Tomiyasu H, Watanabe M, Sugita K, Goto-Koshino Y, Fujino Y, Ohno K, Sugano S and Tsujimoto H: Regulations of ABCB1 and ABCG2 expression through MAPK pathways in acute lymphoblastic leukemia cell lines. Anticancer Res 33: 5317-5323, 2013.

92. Xie J, Jin B, Li DW, Shen B, Cong N, Zhang TZ and Dong P: ABCG2 regulated by MAPK pathways is associated with cancer progression in laryngeal squamous cell carcinoma. Am J Cancer Res 4: 698-709, 2014.

93. El Azreq MA, Naci D and Aoudjit F: Collagen/ $\beta 1$ integrin signaling up-regulates the ABCC1/MRP-1 transporter in an ERK/MAPK-dependent manner. Mol Biol Cell 23: 3473-3484, 2012.

94. Kourti M, Vavatsi N, Gombakis N, Sidi V, Tzimagiorgis G, Papageorgiou T, Koliouskas D and Athanassiadou F: Expression of multidrug resistance 1 (MDR1), multidrug resistance-related protein 1 (MRP1), lung resistance protein (LRP), and breast cancer resistance protein (BCRP) genes and clinical outcome in childhood acute lymphoblastic leukemia. Int J Hematol 86: 166-173, 2007.

95. Baudis M, Prima V, Tung YH and Hunger SP: ABCB1 over-expression and drug-efflux in acute lymphoblastic leukemia cell lines with $t(17 ; 19)$ and E2A-HLF expression. Pediatr Blood Cancer 47: 757-764, 2006.

96. Zhang K, Mack P and Wong KP: Glutathione-related mechanisms in cellular resistance to anticancer drugs. Int J Oncol 12: 871-882, 1998.

97. Tsai SY, Sun NK, Lu HP, Cheng ML and Chao CC: Involvement of reactive oxygen species in multidrug resistance of a vincristine-selected lymphoblastoma. Cancer Sci 98: 1206-1214, 2007.

98. Zhu Z, Du S, Du Y, Ren J, Ying G and Yan Z: Glutathione reductase mediates drug resistance in glioblastoma cells by regulating redox homeostasis. J Neurochem 144: 93-104, 2018.

This work is licensed under a Creative Commons Attribution-NonCommercial-NoDerivatives 4.0 International (CC BY-NC-ND 4.0) License. 